\title{
Jews or Germans? Nationality Legislation and the Restoration of Liberal Democracy in Western Europe after the Holocaust
}

\section{DAVID FRASER AND FRANK CAESTECKER}

Statelessness continues to trouble today's international legal and political spheres. Despite the International Convention Relating to the Status of Stateless Persons, the stateless remain an unwelcome presence and awkward anomaly within an international human rights regime still fundamentally dominated by the nation state structure. ${ }^{1}$ In 1945, Marc Vishniak wrote that the stateless were "... restricted in their rights more than any other people and constitute the weakest chain in the link of human rights." 2 Hannah Arendt, who was herself a Jewish refugee from Germany, placed the enigma of the stateless in an even more central philosophical position. Whereas Visniak emphasized the problematic and marginalized legal status of the stateless within the dominant international paradigm, Arendt proposed a re-imagining of the international legal order, a vision that would prioritize a solution to the situation of the stateless, especially stateless Jews, by "somehow or other restoring to them the inalienable rights of

1. Unravelling Anomaly: Detention, Discrimination and the Protection Needs of Stateless Persons (London: Equal Rights Trust, 2010).

2. The Legal Status of Stateless Persons (New York: American Jewish Committee, 1945), 58.

Frank Caestecker is professor of history at the University College of Ghent and the University of Ghent $<$ Frank.Caestecker@hogent.be $>$. David Fraser is professor of law and social theory at the University of Nottingham $<$ David.Fraser@nottingham. ac.uk>. The authors thank David Tanenhaus and the anonymous reviewers of Law and History Review for their valuable comments on earlier versions of this article. 
man."3 For Arendt, Jewish former citizens of Germany, stripped of their nationality by the Nazi regime, occupied a newly paradoxical situation as empowered and voluntary Heimatlos, precisely because they now rejected the standard legal normativity of the state/citizen template. ${ }^{4}$ Arendt found historical support for her argument about statelessness as both abnormal within dominant international legal thinking, and at the same time strangely empowering, with regard to the situation of the mainly Jewish refugees displaced during World War I. They had fallen outside the protections offered by new succession countries at the end of that conflict, very often by their own decision to refuse incorporation as citizens of the emergent nation states. These Jewish apatrides discovered "privileges and juridical advantages in statelessness." 5 For Arendt, Jewish former citizens of Germany at the end of World War II further embodied a move toward conceptualizing a new international paradigm wherein rights could be sought beyond the traditional bounds of a state-based legal order, precisely because those bounds had been irrevocably shattered by the state itself. ${ }^{6}$

This article engages with this Arendtian paradox by offering a historical examination of the ways in which victims themselves, as well as the authorities of various Western European countries, in the aftermath of World War II, dealt with the policies of the Nazi regime that deprived Jewish Germans of their nationality. The issues that surrounded the question of the "German-ness" of German Jews after the war raised important matters of international and national law, as well as being central to the re-establishment of a liberal legal and political order in Europe. As Pieter Lagrou has written, the stories of Jewish citizens in the immediate aftermath of the war are important "for what they can reveal about the way European countries reconstructed themselves after the catastrophe of Nazism and the degree to which they succeeded or failed to re-invent themselves and evolve towards more open and tolerant societies." 7 John Borneman and Jeffrey M. Peck, in their study of those German Jews

3. Hannah Arendt, "The Stateless People," Contemporary Jewish Record 8 (1945): 137$53,153$.

4. Hannah Arendt, "The Disenfranchised and Disgraced," in The Jewish Writings, eds. Jerome Kohn and Ron H. Feldman (New York: Schocken Books, 2007), 232-35, 235.

5. "The Stateless People," 138.

6. Both space restrictions and the central focus of this article combine to prevent us from a deeper engagement with some of the complexities and contradictions in Arendt's fuller wrtings on the subject, particularly in relation to the difficult questions surrounding the idea and ideal of Israel as a Jewish nation state, a place of refuge for stateless Jews, and the position of that country in Arendtian political philosophy. See for example, "Zionism Reconsidered," in The Jewish Writings, 343-74.

7. Pieter Lagrou, "Return to a Vanished World: European Societies and the Remnants of their Jewish Communities, 1945-1947," in The Jews Are Coming Back: The Return of the 
who chose to return to their native country after the war, write that "... the very category 'Jew' or 'German Jew'... has been a politically contested one- by the Germans in the East and West, by various members and organizations of the international Jewish community, and by the different Allied occupation forces. Moreover, for obvious reasons, many Jews did not want to identify themselves as Jews...." many German Jews opted instead to stop identifying themselves as Germans.

The legal relationship between the signifiers German and Jew at a particular historical juncture is the informing focus of this article. We first deal with the consequences of the Nazi legal categorization of individuals as Jews. This National Socialist racial, legal classification (Jew) and its necessary corollary (Aryan) were and are obviously not transparent, objectively self-evident categories. They are externally imposed and, therefore, very different from self-identification as a member of a religious, ethnic, or sociological community. German Jews, especially those who found themselves in exile outside their native land, had been deprived of their German nationality progressively from 1933 following the coming to power of the Nazis. ${ }^{9}$ Those who survived the Hitler period, in the German Reich or beyond it, found themselves, at the end of the war, presumptively at least, as stateless persons. The technical legal question, which had significant political and cultural import, and which arose after the defeat of the Third Reich, was whether the authorities of the victorious liberal states would give ongoing effect to the deprivation of nationality imposed by the Nazis on these German Jews. Would they continue to consider former German Jews as stateless, or, on the contrary, would these governments and the reconstituted courts of these democracies "restore" these persons' former nationality? The question of the legal categorization "German" became an object of political and legal struggle for many of these Jews in Western Europe.

At first blush, it might appear obvious that liberal governments, as part of their victory over totalitarianism, and within the legal framework of the immediate abrogation of Nazi anti-Jewish laws by the Allied Occupation Authorities, would chose to restore the former German nationality of

Jews to Their Countries of Origin after WWII, ed. David Bankier (Jerusalem: Yad Vashem and Oxford and New York: Berghahn, 2005), 1-24.

8. John Borneman and Jeffrey M. Peck, Sojourners: The Return of German Jews and the Question of Identity (Lincoln and Londen : University of Nebraska Press, 1995), 3.

9. Oscar Janowsky and Melvin M. Fagen, International Aspects of German Racial Policies, (New York: Oxford University Press, 1937); and Michael Hepp, Die Ausbürgerung deutscher Staatsangehöriger 1933-45 nach den im Reichsanzeiger veröffentlichten Listen (Munich: Saur, 1985). 
these Jews as evidence of their complete rejection of Nazi policies and legalized practices of racial, ethnic, and religious persecution. ${ }^{10}$ However, the actual political and legal situation "on the ground" did not necessarily lend itself to such a seemingly principled liberal legal solution consistent with the dominant framework of the state/citizen modus operandi of international law. Many individual Jews challenged the automatic restoration of their former nationality, and demanded a less obvious or straightforward solution to the legal consequences of the persecution they had suffered.

\section{Nationality Legislation and the Holocaust}

In the twentieth century, the political realities of population movements following the Russian Revolution and the exchange of populations between Greece and Turkey, as well as the dissolution of the European empires following World War I, had given rise to a mass of stateless people. ${ }^{11}$ These stateless populations became a new area of concern in international legal thinking, and gave birth to new legal taxonomies and instruments designed to address the problem, even before the coming to power of the Nazi regime and the creation of hundreds of thousands of German refugees. International law attempted to ensure the provision of basic rights to stateless persons by their state of residence. ${ }^{12}$ An international refugee regime was developed in the 1930s, with the specific goal of granting a formal legal status to the stateless so that they were, as Henri De Monneray noted, no longer "des res nullius, des choses sans maître."13

The Nazi state first denationalized Jews and other enemies of the Reich on an individual basis. Almost 8000 Germans became stateless as a result of this individualized stage of the Nazi legal process of stripping Jews and

10. Law No. 1, Abrogation of Nazi Law, Military Government Germany, Supreme Commander's Area of Control; and "L'Abrogation des Lois Nazies," in Maurice Ruby, L'Évolution de la Nationalité Allemande d'après les Textes 1842-1953, (Baden-Baden: Werveries, 1954), 266-67. We thank Patrick Weil for bringing this work to our attention.

11. Catherine Gousseff, L'exil russe 1920-1939: La fabrique du réfugié apatride (Paris: CNRS, 2008); Susanne Heim, "International Refugee Policy and Jewish Immigration under the Shadow of National Socialism," in Refugees from Nazi Germany and the Liberal European States, ed. Frank Caestecker and Bob Moore (New York and Oxford: Berghahn, 2010), 17-47; and Claudena M. Skran, Refugees in Inter-War Europe: the Emergence of a Regime (Oxford: Oxford University Press, 1995).

12. Paul Weis, Nationality and Statelessness in International Law, 2nd revised ed. (The Hague: Sijthoff \& Noordhoff, 1979).

13. Henri De Monneray, "Commentary," Revue Critique de droit international privé 36 (1947): 119-26; and Ruby, L'Évolution de la Nationalite Allemande, 266-67. 
political adversaries of their citizenship. ${ }^{14}$ Those without a state, then as now, were considered a problematic and troubling legal category. ${ }^{15}$

From 1938 onwards, Jews fleeing Nazi Germany could claim protection under the Geneva Convention for Refugees Coming from Germany. However, very few states formally adopted this specific international refugee regime. The only states to do so before the war were Belgium and Great Britain, which both ratified this Geneva Convention in $1939 .{ }^{16}$ The traditional abhorrence of the status of apatride meant, however, that German Jews residing in liberal European countries were, in practice, entitled to some kind of refugee status. This refugee status that the French Court de Cassation qualified in 1950 as a "quasi-nationality" was naturally seen by most political and legal authorities as inferior to real nationality. ${ }^{17}$ The traditional view was that "possessing" a nationality offered considerable advantages associated with membership in the community of nations, that is: having a territory to which access could not be refused, the diplomatic and other protections offered by a state, or having a passport that facilitated international travel, and this perspective dominated. Few commentators, even after the war, were willing to accept the Arendtian view that "statelessness" could in some circumstances be a politically powerful or even desirable legal status.

The number of stateless former Germans increased in the years following the Nazi rise to power. The Reich Citizenship Law of September 15, 1935, one of the so-called Nuremberg Laws, moved away from the individualized denaturalization and denationalization model and applied a collective approach to Germans of Jewish origin. The distinction between subject and citizen, between German Jews and so-called Aryans, laid the groundwork for the series of exclusionary measures passed as supplementary decrees to the Citizenship Law. These successive supplementary decrees progressively separated Jewish Germans from their fellow countrypeople, legally, economically, psychologically, and physically. The process culminated with the 11th Decree ofNovember 24, 1941, which stripped all German Jews who had left the German Reich of their nationality. The Decree applied to all Jewish Germans who had their "ordinary abode" (gewöhnlichen Aufenthalt) abroad. Anything other than a mere passing

14. Janowsky and Fagen, International Aspects of German Racial Policies, 217-28.

15. Lawrence Preuss, "International Law and the Deprivation of Nationality," Georgetown Law Journal 23 (1935): 250-76; Jane Perry Clark Carey, "Some Aspects of Statelessness Since World War I," American Political Science Review 40 (1946): 113-23; Maurice Loisel, "Les anamolies des lois sur la nationalité: doubles nationaux et apatrides," Population 6 (1951): 249-60; and Helen Silving, "Nationality in Comparative Law," American Journal of Comparative Law 5 (1956) 410-42.

16. Heim, "International Refugee Policy," 44.

17. Ruby, L'Évolution de la Nationalité Allemande, 267. 
presence outside Germany fulfilled the "abode" requirement, regardless of the intention or motivation behind the absence from German territory. The Decree applied not only to refugees and exiles but also to those deported to camps in Poland and elsewhere. These German Jews had, as a matter of law, their ordinary abode in "Auschwitz." 18 As a result, they were no longer considered German citizens under German law. From 1944, as more and more European territory was liberated, tens of thousands of Jewish Germans who had fled Hitler's persecution and extermination plans by seeking refuge outside the limits of German territory, as well as those who had been caught up in, but who had survived, the Nazi death machine, still found themselves without a formal, legal, national identity. The 11th Decree had rendered them stateless.

\section{The Effect of Denationalization of German Jews During the War}

During the war, the German authorities had declared all German Jews in the territories under their control to be stateless. Depending upon the nature of the occupation, this was done with varying degrees of support from the local administration. For example, in Belgium, local officials had immediately given full force and effect to the provisions of the 11th Decree by marking all identity papers of former German Jews and modifying local police and other municipal population records to indicate their new stateless situation. ${ }^{19}$

The position of German Jews in the United Kingdom differed from that under which refugee Jews lived in occupied continental Europe. When the war broke out, and especially after the fall of France in 1940 and with the threat of imminent invasion, many Jewish refugees in Britain fell, as Germans, under the definition of enemy aliens and were therefore liable to indefinite internment. ${ }^{20}$ This meant that German Jews often found themselves imprisoned side by side with Nazi sympathizers. For the British government, at war with Germany, many of these Jews were more obviously Germans than victims of Nazi persecution. ${ }^{21}$

18. Alfred Kauffmann, "Denationalization and Expropriation," The Law Journal 92 (1942): 93; and Paul Abel, "Denationalization", Modern Law Review 6 (1942): 57-68.

19. David Fraser, The Fragility of Law: Constitutional Patriotism and The Jews of Belgium, 1940-1945, (Abingdon, Oxford, and New York: Routledge, 2009), 123-28.

20. Todd M. Endelman, The Jews of Britain 1656 to 2000 (Berkeley and Los Angeles: University of California Press, 2002), 223-26; Gerry R. Rubin, "Don't Mention the War! R. v. Bottrill, ex parte Kuchenmeister (1946) Revisted," Journal of Legal History 28 (2008): 309-33.

21. A.W. Brian Simpson, In the Highest Degree Odious: Detention without Trial in Wartime Britain (Oxford: Clarendon, 1994), 107; David Cesarani, "An Alien Concept? 
This policy was implemented against German Jews despite the fact that many individuals had previously been recognized as stateless persons by the British government's own immigration and police officials upon or after their arrival in the United Kingdom. ${ }^{22}$ However, this bureaucratic "recognition" was situated only at the de facto level. In British policy and domestic legal practice, "refugee" or "stateless" were not official administrative categories, let alone recognized juridical categories, notwithstanding the country's ratification of the Geneva Convention of 1938.23 The stateless or refugee status derived from bureaucratic record keeping and local police activities did not, therefore, determine or even influence the definition of "enemy alien" as applied by competent wartime British authorities. During the war, German Jews remained officially documented as German nationals, but at the same time, most were eventually considered "refugees from Nazi oppression," and their identity documents could even carry this designation. ${ }^{24}$ As a result, individuals could be stateless insofar as their pre-war status as recorded by local police and immigration officials was concerned, and still be considered an enemy alien for purposes of internment or other police and security purposes following the outbreak of hostilities between the United Kingdom and the Third Reich.

The introduction of mass denationalization under the 11th Decree had significant effects for many German Jewish refugees living in Britain. The loss of German nationality constituted the final separation from their former homeland. Some, especially those still interned, sought to turn this aspect of Nazi legalized anti-Semitism to their own advantage. Because they were no longer German, they argued, they were once and for all legally and formally stateless and as a result, no longer "enemy aliens" liable to internment. Basing themselves on the traditional international law principle that the legal determination of nationality is within

The Continuity of Anti-Alienism in Brtiish Society Before 1940," in The Internment of Aliens in Twentieth Century Britain, eds. David Cesarani and Tony Kushner (London: Routledge, 1993), 25-52, 42-44; and Tony Kushner, "Clubland, Cricket Tests and Alien Internment, 1939-40," in The Internment of Aliens in Twentieth Century Britain, 79-101.

22. Yvonne Kapp and Margaret Mynatt, British Policy and the Refugees, 1933-1941 (London: Frank Cass, 1997), 47-65.

23. Louise London, Whitehall and the Jews, 1933-1948: British Immigration Policy and the Holocaust (Cambridge: Cambridge University Press, 2000), 84-85, 101-112.

24. Note on the status of refugees coming for Germany in Belgium prepared by Sir Herbert Emerson and Dr. G. G. Kullmann of the High Commissariat of Refugees, under the protection of the League of Nations and the Intergovernmental Committee for Refugees on the request of Mister De Visscher. November 10, 1944, National Archives Brussels, Alien Police (1930-1960), 1 B6. 
the sole jurisdiction of the state with which the individual has the original intimate relationship, in this case, Germany, these Jews asserted that British law was bound to give effect to the denationalization decision of the sovereign German state. ${ }^{25}$ In addition, the Aliens' Division and the Nationality Division of the Home Office were flooded with requests for a change in status by German Jews who were not subject to internment, demanding their re-classification as stateless. Local police stations witnessed an influx of Jewish refugees seeking to have their new status recorded on their passports and other official documents. ${ }^{26}$ In particular, readers of the émigré newspaper Die Zeitung attempted to have their status officially changed after exiled German lawyer Alfred Kauffmann published an article setting out the legal argument that German Jews in England should henceforth be considered as stateless. ${ }^{27}$

Advice from government lawyers, however, indicated that demands for release from internment and detention based on a change in status from "enemy alien" to "stateless" as a result of the 11th Decree would be contrary to public policy in a time of war. ${ }^{28}$ The British courts followed this line of argument and found that national security interests demanded that they refuse to give effect to Nazi denationalization laws by ordering the release of interned German Jews. The rationale was straightforward "... Such changes of nationality are not recognized for obvious reasons. If such changes were to be permitted in time of war enemy agents might acquire facilities which could be used in a way very much to the prejudice of this country." 29

The British courts, therefore, had cogent reasons to reject the idea that Nazi law could determine, while the United Kingdom was at war with Germany, who should be interned under national security legislation. As the war drew to a close, however, general principles of international law would, it was argued, require the United Kingdom to recognize the statelessness of German Jews resident in the United Kingdom. ${ }^{30}$

25. Abel, "Denationalization"; and "Effect of the German Denationalization Decree of November 25th, 1941," Modern Law Review 8 (1945): 77-80.

26. Correspondence in the Home Office, December 1941 to March 1942, HO 213/160, National Archives, Kew.

27. "Die Rechtsstellung der Refugees", Die Zeitung, March 13, 1942, p. 2.

28. The Legality of the Internment of German Jews Deprived of Their German Nationality, May 4,1942, HO 213/160, National Archives, Kew.

29. Ex parte L. [1945] K.B. 7, 8.

30. Hersch Lauterpacht, "The Nationality of Denationalized Persons," Jewish Yearbook of International Law (1949): 164-85; Sefton W. D. Rowson, "Some Private International Law Problems Arising Out of European Racial Legislation, 1933-1945," Modern Law Review 10 (1947): 345-62. 


\section{Allied Victory and the Abolition of Nazi Legality in Occupied Germany (1944-1946): Did Jews Become Germans Again?}

Most policy makers in the various Allied governments and those running the occupation regime in Germany believed that, after years of Nazi oppression and persecution, Jewish survivors would simply return to their prewar homes and reconstruct their lives. ${ }^{31}$ The specificity of the Jewish experience of the Shoah was not immediately understood, acknowledged, or taken into account. Jewish survivors were indiscriminately included among all those uprooted by the war. They were simply placed in the generic category of displaced persons (DPs). ${ }^{32}$ In addition to the problems surrounding the return of Jewish citizens to their prewar homes, Western governments and the Occupation Authorities in Germany faced additional complications caused by the presence of a significant number of Eastern European DPs who did not wish to return to the Soviet bloc.

Approximately 9,000,000 DPs were repatriated in the immediate postwar period, among them approximately 2,200,000 Soviet citizens-forced laborers, prisoners of war, and war refugees - who during the war had been displaced to the West. The Soviet Union had even obtained Allied consent at Yalta for the use of force to compel the return of DPs of Soviet nationality. This compulsion was justified by the presence among DPs of a significant number of Soviet citizens who had actively collaborated with the Nazis. The nationality issue immediately came to the fore as the Soviet Union claimed that people living on territory acquired after August 1939 were Soviet subjects who had to return. The Western allies, however, only accepted the (forced) return of those Soviet citizens who had lived within the September 1939 borders of the Soviet Union. Objections were also raised to the broad Soviet definition of "collaboration," which could include those enrolled in forced labor. The Americans stopped forced

31. Michael Brenner, After the Holocaust: Rebuilding Jewish Lives in Postwar Germany (Princeton: Princeton University Press, 1997), 100-21; Ruth Gay, Safe Among the Germans. Liberated Jews After World War Two (New Haven: Yale University Press 2002), 133-34; Zeev Mankowitz, Life Between Memory and Hope: The Survivors of Holocaust in Occupied Germany (Cambridge: Cambridge University Press, 2002), 11-23; Jay Howard Geller, Jews in Post-Holocaust Germany, 1945-1953 (Cambridge: Cambridge University Press, 2005), 1-16; and Atina Grossmann, Jews, Germans, and Allies: Close Encounters in Occupied Germany (Princeton: Princeton University Press, 2007), 88-129.

32. Michael Berkowitz and Suzanne Brown-Fleming, "Perceptions of Jewish Displaced Persons as Criminals in Early Postwar Germany: Lingering Stereotypes and Self-fulfilling Prophecies," in "We Are Here": New Approaches to Jewish Displaced Persons in Postwar Germany, eds. Avinoam J. Patt and Michael Berkowitz, (Detroit: Wayne State University Press, 2010), 167-93; Hagit Lavsky, "The Experience of Displaced Persons in Bergen-Belsen: Unique or Typical Case?" in "We Are Here," 227-56. 
repatriation from their occupation zone in May 1946, and the British followed suit in 1947, as part of the slowly emerging Cold War, and, perhaps, of a nascent international human rights regime. ${ }^{33}$ Because of this change in Western policy, approximately 1,000,000 Polish, Baltic, and other DPs in occupied Germany, of whom $20 \%$ were Jews, were not subject to repatriation.

United States occupation forces under General Dwight Eisenhower had received specific and apparently unambiguous orders in April 1945 concerning the nature and substantive normative content of military rule in occupied Germany. Paragraph $6 \mathrm{~b}$ of the relevant Directive provided "The laws purporting to establish the political structure of National Socialism and the basis of the Hitler regime and all laws, decrees and regulations which establish discrimination on grounds of race, nationality, creed or political opinions should be abrogated by the Control Council. You will render them inoperative in your zone." 34

In the postwar vision of the occupiers (at least of the three Western powers: the United States, the United Kingdom, and France), a new, democratic, and liberal Germany would emerge from the defeat and again be a home to Jews. The Allied Control Council in occupied Germany formally revoked Nazi nationality legislation and other anti-Jewish measures on September 20, 1945 pursuant to Control Council Law No.1. But the revocation of Nazi anti-Jewish laws, especially insofar as the nationality question was concerned, was not as straightforward in practice as it might have appeared. ${ }^{35}$

One view of public international law, perhaps the dominant interpretation, maintained that the question of citizenship should be determined solely by the state from which the individuals originated. In other words, German law should determine who qualified as nationals of that country. In the immediate aftermath of the war, this was, of course, complicated by the fact that Germany was now under Allied occupation and the legal system of the German state was and would remain for some time, de facto, if not necessarily, de jure, nonexistent or inoperative. ${ }^{36}$ The question

33. Lieselotte Luyckx, Soviet DP's for the Belgian mining industry (1944-1960): The daily struggle against Yalta of a forgotten minority (unpublished $\mathrm{PhD}$ diss., European University Institute Florence, 2012); and Pavel Polian, Deportiert nach Hause: Sowjetische Kriegsgefangene im "Dritten Reich" und ihre Repatriierung (Munich: Oldenbourg, 2001).

34. Directive to the Commander in Chief of United States Forces of Occupation Regarding the Military Government of Germany, Issued April 1945, and published October 17, 1945, Department of State Bulletin, July-December 1945, 598.

35. Control Council Law No. 1, OG/CC, No. 1, 6 (October 29, 1945).

36. Compare Hans Kelsen, "The Legal Status of Germany According to the Declaration of Berlin," American Journal of International Law 39 (1945): 518-26; Robert Y. Jennings, "Government in Commission," British Yearbook of International Law (1946): 112-41; 
of the nationality status of "former" German Jews, as re-instated German nationals or as still stateless, was open to different, often opposed, legal interpretations and political exigencies. Hersch Lauterpacht, Whewell Professor of Law at the University of Cambridge, summarized the general legal norms that, in his view, had to be applied to the Allied Occupation Authority's position under Control Council Law No. 1. He put forward two basic principles. First among these was the idea that laws are presumptively prospective. "The legal effect, properly conceived, of the repeal of the Law of Citizenship of 1935 and the Decree of 1941 is that in the future no German Jew shall lose his German Nationality because of taking up habitual residence abroad. Its effect is not that the persons who lost their German nationality because of the operation of the Decree are automatically reinstated in the German nationality."37

Second, from general justice and autonomy principles, Lauterpacht asserted that the effect of the denationalization measures adopted by the Nazis had been to rupture all legal ties between individual Jews and the German state. A new government of Germany could not (re)impose German nationality on these former citizens nor, a fortiori, could an Occupying Authority take any such measures under its necessarily limited jurisdiction. It might offer to reinstate the former citizenship status of individuals, but the initiative and decision rested not with the government but with the person concerned. ${ }^{38}$

The legal principles that Lauterpacht invoked found a favorable reception in the United States. There was a growing political consensus that Jews in postwar Europe should be treated as a class apart. President Truman had named a special representative to investigate the situation of Jewish survivors in occupied Germany. Earl G. Harrison, Dean of the University of Pennsylvania Law School, was sent to Germany in the summer of 1945. Harrison concluded his investigations and pleaded for the recognition of a special status for Jewish DPs. ${ }^{39}$ This distinct position was necessary, because Jews had been persecuted more barbarically than any other group by the Nazis, and, therefore, they constituted a group with greater and specific needs. His advice was heeded, in the American zone at least. In occupied Germany, the Americans were the first to provide

Wol Friedmann, The Allied Military Government of Germany (London: Stevens and Sons, 1947); and Josef L. Kurz, "The Status of Occupied Germany under International Law: A Dilemma," Western Political Quarterly 3 (1950): 538-65.

37. Lauterpacht, "The Nationality of Denationalized Persons," 170.

38. Ibid., 171-72.

39. The Treatment of Displaced Jews in the United States Zone of Occupation in Germany, 1945, Report of Earl G Harrison to President Truman. 
facilities specifically for Jews. They established all-Jewish DP camps, which by the end of 1946 accommodated approximately 145,000 individuals, mostly non-Germans from Eastern Europe. ${ }^{40}$ At the same time, the actual fate of Jewish DPs, the determination of their nationality, and their final destination upon release from the camps, continued to vex American policy. One contemporary observer wrote that "(f)inally, the most difficult problem of all was represented by the some 20,000 to 30,000 German Jews and other Germans who had been inmates of Nazi concentration camps. The Jews, almost without exception, desired new homes in Palestine, and all persecutees loathed the very thought of remaining in Germany." 41

British occupation officials, on the other hand, were very reluctant to embrace the American practice of recognizing a Jewish specificity. Government authorities in Britain maintained that the effect of the repeal of Nazi race laws was to restore German nationality on a universal basis. ${ }^{42}$ In the summer of 1945, the British officials on the Control Commission insisted on the "renationalization" of Jews present on German territory. This, they argued, was the automatic result of the abrogation of Nazi race laws. The British insisted on the re-establishment of nonracial liberal legality in Germany. The United Kingdom was unwilling to accept the findings of the Harrison Report, which it rejected as anecdotal and unscientific, because the inference was that a home outside of Germany had to be found for the Jews. British officials asserted that whereas a real investigation of the situation would perhaps demonstrate that "some Jews must be removed," this could be dealt with by small-scale emigration to other countries such as the United States, which "must take their share." 43 More significantly, the British "Palestine problem" demanded that they continue to refuse to acknowledge any kind of Jewish specificity. ${ }^{44}$ Because the question of Palestine loomed so large, resettlement of German Jews in Germany had a significance beyond the general boundaries of the immediate resettlement problem for DPs. As a

40. Brenner, After the Holocaust, 16-18; Tony Kushner, The Holocaust and the Liberal Imagination (Oxford: Blackwell, 1994), 229-31; and Daniel Cohen, "Between Relief and Politics: Refugee Humanitarianism in Occupied Germany 1945-1946," Journal of Contemporary History 43 (2008): 437-50.

41. Malcolm J. Proudfoot, "The Anglo-American Displaced Persons Program for Germany and Austria," American Journal of Economics and Sociology 6 (1946): 33-54.

42. Foreign Office Memorandum, November 1945, HO213/952, National Archives, Kew.

43. Cabinet Meeting, October 11, 1945, C. M. 40 (45), CAB 195/3, National Archives, Kew.

44. Cabinet Meeting, January 1, 1946, C. M. 1 (46), CAB 195/3, National Archives, Kew.; Minutes of Cabinet Meeting, October 4, 1945, CM 38 (45); Minutes of Cabinet Meeting, October 11, 1945, CM 40 (45), CAB/195/3, National Archives, Kew. 
result, British military authorities in Germany did not grant German Jews preferential treatment or even protection in cases of ongoing discrimination by German officials. They continued to consider these Jews as Germans who had to resettle in Germany.

From 1945, the Americans formally opposed the compulsory (re)imposition of German nationality on Jews. They insisted that Council Law No.1 had no retrospective effect on German nationality law. One year later, the British and French authorities in occupied Germany finally agreed with the legal interpretation that persons who had been deprived of German citizenship did not automatically regain it. ${ }^{45}$ As far as the Control Council was concerned, these Jews remained stateless as a consequence of their denationalization under Nazi law from 1933 onwards. ${ }^{46}$ There would be no collective "renationalization" of former German Jews. Jews who sought to regain their previous German citizenship could do so, as of right, by making a formal request. This position embodied a legal and political recognition that the actual impact of Nazi nationality legislation was real, long lasting, and significant for all those affected by it. It eschewed any idea that the abrogation of Nazi race laws ipso facto re-established the nationality of former German Jews and served as the formal recognition of the notion articulated by Hannah Arendt that "statelessness" could in the circumstances be preferable to German-ness.

The British (and the French) in their occupation zones had been compelled by the political reality of occupation policy to follow the American example in relation to Jewish DPs. For the French authorities in Germany, the matter was of less practical import because the French Zone was home to only 1,000 Jews in camps or in agricultural colonies known as Kibbutzim. ${ }^{47}$ The United Kingdom government had, as was mentioned, initially been unwilling to recognize stateless Jews who could claim that they had no desire to remain in Germany and instead would probably insist on emigrating to Palestine. Eventually, the British had to yield to the American position. ${ }^{48}$ As early as the summer of 1945 , some of the same

45. Response to Danish Military Mission in Germany, July 24, 1946, ALP/452/20.801 (A) quoted in Ruby, L'Évolution de la Nationalité Allemande, 258-59.

46. Lauterpacht, "The Nationality of Denationalized Persons," 164-85.

47. Juliane Wetzel, "Les camps pour personnes déplacées en Allemagne de 1945 à 1957," Vingtième Siècle 54 (1997): 79-88; and Françoise Ouzan, "La reconstruction des identiés juives dans les camps de personnes déplacées d'Allemagne (1945-1957)," Bulletin du Centre de recherche français de Jérusalem 14 (2004): 35-49.

48. In November 1945, British officials in Germany were instructed to stick to their position that Jews were to be renationalized, but they also were told to avoid seeking any agreement from the Allied Control Council in this matter. In June 1946, Home Office legal advice had declared that the German nationality of formerly denationalized German Jews in the British zone was restored automatically, but only following the explicit request of the 
British authorities on the Control Commission in Germany, who had previously insisted on the renationalization of Jews in Germany, were still apparently willing to mitigate the effect of the abolition of Nazi law on German Jews resident in Britain. For those Jews, only a specific individual "opt in" could restore their previous nationality. Such a position appears to have been taken based on the view that under international law, any Control Council decision was territorially limited to occupied Germany. ${ }^{49}$ Following a traditional, and state-centered interpretation of international law, the British officials in Germany who adopted this position in favor of the continuing statelessness of some German Jews, insisted that authorities in the United Kingdom had no say in German nationality law. This was also the position first adopted by Dutch military authorities in early 1945. The confirmation of the statelessness of Jews who had fled Nazi Germany to the Netherlands was informed by the desire not to equate them with Dutch collaborators and Germans who had been involved in the occupation of that country..$^{50}$

\section{Jews, Germans, Nazi Legality and Injustice in Liberal Democracies}

In 1945, the effect of the abolition of Nazi law on (former) German Jews resident in Britain, Belgium, France, and the Netherlands was not at all homogeneous. Whereas the American and French Occupation Authorities, Dutch military officials, and some members of the British Control Commission advocated maintaining the statelessness of former German Jews, this was not the position of the civil authorities in Britain or Holland. In the United Kingdom, the Foreign and Home Office officials who dealt with the question strongly objected to retaining the effect of Nazi racial laws. ${ }^{51}$ For them, the traditional international law view that

individual concerned. Ruby, L'Évolution de la Nationalité Allemande, 258-59. Foreign Office Memorandum, November 1945, HO213/952, National Archives, Kew.

49. Letter of November 10, 1944 from Ian L.Henderson, Foreign Office to Home Office, HO 213/199. National Archives, Kew. In May 1945, the British Control Commission received legal advice that a unilateral imposition of German nationality on former German citizens who were outside the territorial limits of Germany would be ultra vires the Control Commission. Letter of May 17, 1945 from Control Commission to the Foreign Office, HO213/951, National Archives, Kew.

50. Corrie K. Berghuis, Geheel ontdaan van onbaatzuchtigheid, Het Nederlandse toelatingsbeleid voor vluchtelingen en displaced persons van 1945 tot 1956 (Amsterdam: Thela, 1999), 23.

51. Letter of May 17, 1945 from the Control Commission, HO 213/951/952 and the response of Sir F. Newsam, May 28, 1945, HO 213/951, National Archives, Kew. 
statelessness was "an undesirable position" in international law and one to be avoided if possible, held sway. ${ }^{52}$ The Foreign Office adopted the view that it was clearly permissible under both domestic and international legal norms to confer nationality "on persons in other countries." In effect, they argued, this was not even an accurate legal description of the situation. There was no "imposition" of German nationality. Instead, by abolishing the "illegal, unjust, and fundamentally invalid legislation" of the Nazi state, the United Kingdom was simply restoring the legal status quo ante and (re)establishing a liberal legal order that was also consistent with international law's abhorrence of statelessness. ${ }^{53}$ Jews from Germany in Britain remained German; ${ }^{54}$ however, these German Jews were still treated differently from other Germans, as part of the de facto refugee policy to which the British authorities continued to subscribe. This concession did not formally change the legal position of Jewish Germans. They remained German nationals and could still be classified as enemy aliens. ${ }^{55}$

In Belgium, as early as October 6, 1944, the German nationality of Jewish survivors whose citizenship had been annulled in 1941 under the 11th Decree, was restored. Those who had lost their German citizenship before May 1940, when Belgium fell to the German onslaught, and before the 11th Decree, however, remained stateless. This restoration of the nationality of most German Jews present in Belgium was portrayed as an expression of the complete rejection, by the newly installed democratic government, of the Nazi distinction between Jews and Aryans. It was explicitly meant as a return domestically to the traditional Belgian policy of nondiscrimination on religious and, a fortiori, on racial or ethnic grounds. There was little or no understanding in liberal governmental and legal circles of any possible objections to this restoration of German nationality. Belgian officials considered that maintaining the statelessness of German Jews was simply not in the interest of the Jews themselves. What had been taken away because of Nazi racial persecution in legal form had to be restored. ${ }^{56}$ As late as 1947 , the Belgian socialist jurist and minister of the interior, Piet Vermeylen, echoed the familiar view that statelessness

52. Letter of November 10, 1944 from Ian L. Henderson, Foreign Office to Home Office, HO 213/199, National Archives, Kew.

53. Letter from John M. Troutbeck, June 22,1945, HO 213/951, National Archives, Kew.

54. Weis, Nationality and Statelessness in International Law, 121.

55. Minute Sheet, Home Office Aliens' Department, October 1945, HO 213/951, National Archives, Kew; Foreign Office Memorandum; and Rubin, "Don't Mention the War!".

56. Frank Caestecker, "Holocaust Survivors in Belgium 1944-49: Belgian Refugee Policy and the Tragedy of the Endlösung," Tel Aviver Jahrbuch für Deutsche Geschichte 27 (1998): $358-59$. 
was a status to be avoided in both national and international legal regimes. He declared that it was "infinitely preferable" (infinement préférable) that these people be citizens of some country. For Vermeylen, it was obviously better to have a "bad" nationality than to have none. ${ }^{57}$

In the Netherlands, there was disagreement on how to handle the nationality question as a lingering aspect of Nazi legalized antiSemitism. Because of the circumstances of the war, the decision by Dutch authorities to restore the German nationality of Jews came half a year after similar action by the Belgians. Whereas by September 1944, Belgium and the southern part of the Netherlands had been liberated, German control of the rest of the Netherlands lasted until May 1945. During this interlude, Dutch military authorities had classified Jews from Germany as stateless. Civilian officials took over from the military in April 1945 and quickly changed the Dutch position by recognizing the German nationality of Jewish refugees. The minister of justice, Hans Van Kolfschoten, argued that his decision to restore the German nationality of these Jews was a straightforward application of international law. A law passed by a state in a time of war had no binding effect beyond the original territory of that state. ${ }^{58} \mathrm{He}$ further legitimized his decision as an absolute refutation of racial, ethnic, and religious discrimination in Nazi law. This total rejection of Nazi legality and the anti-Semitic normative order of the Hitler regime was, according to Van Kolfschoten, completely consistent with the central postwar aims of all Allied authorities. ${ }^{59}$

In France in 1945, some courts held that the effect of Control Council Law No. 1 was to restore the status quo ante and to reinstate the original nationality of exiled German Jews. ${ }^{60}$ Other French tribunals, however, rejected this view and found that absent a specific choice by individuals to seek the restoration of their German nationality, the effect of the 11th Decree still operated and such a person was to be considered stateless (apatride). ${ }^{61}$ This legal dispute between various lower courts was apparently settled by the Chambre Sociale of the Court of Cassation, which held without further explanation in the case of Kurzmann c. O'héa (November 26, 1946) that the juridical effect of the Allied abolition of Nazi anti-Jewish

57. Vermeylen to Goldstein, March 11, 1947. Archives Auschwitz Foundation Brussels, Papers Maurice Goldstein, 12.

58. Berghuis, Geheel ontdaan van onbaatzuchtigheid, 21.

59. Ibid., 20-24; and Martin Bossenbroek, De Meelstreep: Terugkeer en opvang na de Tweede Wereldoorlog (Amsterdam: Bert Bakker, 2001), 258-9.

60. Tribunal civil Seine, October 30, 1945.

61. Ruby, L'Évolution de la Nationalité Allemande, 262-67. 
laws had been to automatically re-impose German nationality on previously denationalized German Jews. ${ }^{62}$

This reasoning was apparently influenced by other French attempts to re-establish republican legality. One of the first pieces of legislation of the Vichy regime had been the French Nationality Law of July 22, 1940, which established an administrative mechanism for reviewing all naturalization decisions taken since 1927 . This Pétainist reaction to the perceived perfidy of the Third Republic embodied a barely disguised anti-Semitism and a fascistic vision of la vraie France, with the necessary corollary of a restricted understanding of nationality and citizenship. This 1940 law carried with it clear echoes of early Nazi efforts to rid the country of disloyal nationals, Jews, and politically suspect others. A commission was established to review and adjudicate on all naturalizations that had taken place under the Popular Front government. By September 1943, almost every third Jew naturalized in France between 1927 and 1940 had lost his or her new nationality; 63 15,154 individuals were deprived of their French citizenship under these legal processes during the Vichy period. The newly (re)established French Fourth Republic, by the ordinance of May 22, 1944, declared the collective and "retroactive" re-naturalization of these French Jews. The Court of Cassation in Kurzmann c. O'héa decided to restore the German nationality of other Jews in similar terms.

As a direct consequence of the legal aspect of the victory over Nazism, which found in the abrogation of Nazi race laws an automatic restoration of German nationality for German Jews in France, Belgium, and the Netherlands, these victims of Nazism were transformed from stateless refugees into citizens of what remained an enemy state. In the immediate aftermath of the war, that state, Germany, was a defeated and occupied territory without effective sovereignty. Lauterpacht summarized the ethical and international legal dilemmas that arose as a result of the automatic renationalization of Jewish refugees when he wrote:

The repealing legislation of the Allied authorities in Germany would, in a substantial respect, fail in its purpose if the victims of the persecution were, as a result of enactments intended to remove them from the burdens of discrimination, made to suffer from measures adopted against German

62. Ernst Mezger, 'Spoliation' Nouvelle Revue de Droit International Privé 13 (1946): 565-68; and Henri Monneray, 'Réfugiés allemands' Revue Critique de Droit International Privé 36 (1947): 118-19.

63. Patrick Weil, Qu'est-ce qu'un Français? Histoire De la Nationalité Française Depuis la Révolution (Paris : Gallimard, 2005), 143-202; and Bernard Laguerre, "Les Dénaturalisés de Vichy 1940-1944," Vingtième Siècle 20 (1988): 3-15. 
nationals and intended as just compensation from and punishment of their persecutors. It is improbable that, in addition to the clear legal merits of the issue, these considerations of equity and morality would be disregarded by an international tribunal. ${ }^{64}$

In France, a series of special measures adopted by the government at the time of liberation was aimed at eliminating the most pernicious effects of anti-Jewish persecutory measures, such as the deprivation of property by Aryanization. Those unjustly evicted from their premises, as owners or as renters, could lodge claims permitting them to regain access to their abodes. Other general measures targeting economic and social deprivations brought about by the consequences of war were also adopted. ${ }^{65}$ If former German Jews were classified as stateless, they could benefit under French domestic regulations from these social welfare programs and, in appropriate cases, from the right to regain their former residences. The decision of the French Court of Cassation in Kurzmann, and the previous decisions adopted by some lower courts classifying these Jewish individuals as German following the abrogation of Nazi race laws, had a pernicious result. These formerly stateless Jews, now Germans once more, were to be treated under French law as ineligible for "reintegration" to their former residences and as ineligible for any social welfare benefits because they were now, again, enemy subjects. ${ }^{66}$

The consequences of being enemy aliens could be even more dramatic than the loss of access to welfare and housing benefits. The newly liberated liberal democracies had enacted legislation to deprive German nationals residing within their territory of their right of abode. With the liberation of Belgium and the Netherlands, for example, Germans remaining in these countries and who had been involved in the occupation, were to be expelled following internment and investigation of their wartime activities. Their property was sequestered. Former German Jews were not spared from the suspicion that fell on all Germans. As a result of the decision of the Belgian and Dutch authorities to eradicate the legal heritage of Nazi racial discrimination, survivors from Germany and Austria who had

64. Ruby, "The Nationality of Denationalized Persons," 174-75.

65. Renée Poznanski, Etre juif en France pendant la Seconde Guerre mondiale (Paris: Hachette, 1994), 673-77; Renée Poznanski, "French Apprehensions, Jewish Expectations: From a Social Imaginary to a Political Practice," in The Jews Are Coming Back, 25-57; and Leora Ausländer, "Coming Home? Jews in Postwar Paris," Journal of Contemporary History 40 (2005): 237-59.

66. Ernst Mezger, 'Spoliation' Nouvelle Revue de Droit International Privé 13 (1946): 565-68; Henri Monneray, 'Réfugiés allemands' Revue Critique de Droit International Privé 36 (1947): 118-19; and De Monneray, Tribunal civil Seine (October 30,1945) quoted in Ruby, L'Évolution de la Nationalité Allemande, 264. 
found asylum in Belgium and the Netherlands and still resided there after the war, were put on the same legal footing as their non-Jewish countrymen. For the Belgian and Dutch state officials, they were first and foremost Germans, citizens of the country that had occupied their territory in 1940. According to formal legal instructions in both countries, all enemy aliens had to be interned pending the investigation of their "attitude" during the war.

The mere fact of survival as a Jew appeared to mean for Belgian and Dutch officials that a large number of those German Jews must have been collaborators. ${ }^{67}$ These suspicions were based, in part, on the role believed to have been played by German Jews during the war in the official representative Jewish organizations established by the German occupation authorities. ${ }^{68}$ Even among national Jewish communities, it was commonly believed that some German Jews had behaved more as Germans than as Jews during the occupation. As a result, after liberation, approximately 100 German Jews in Belgium, and an unknown number in the Netherlands, became victims of the witch hunt against everything German. They were interned as enemy aliens, together with German Nazis. ${ }^{69}$

That victims were interned, together with perpetrators, on the basis of their common "nationality," provoked local and international outrage. 70 In Antwerp, an American soldier, Sergeant Kurt Stern, informed the

67. Caestecker, Holocaust Survivors in Belgium, 353-59, 375. Belgian jurist Georges Crassart wrote in 1944 that agents of a German fifth column were being recruited among German Jews. Georges Crassart, L'internement des suspects et des étrangers. Arrêté-loi du 12 octobre 1918 et son application en 1944 (Bruxelles: 1944), 26.

68. On the role of German Jews in the organization of the persecution in Belgium, see Maxime Steinberg, 1942 : Les cents jours de la déportation des Juifs de Belgique (Brussels: Vie Ouvrière, 1984), 38-43; and Jean-Philippe Schreiber and Rudi Van Doorslaer, eds., Les Curateurs du Ghetto: L'Association des Juifs en Belgique sous l'Occupation Nazie (Brussels: Labor, 2004).

69. Dienke Hondius, Terugkeer: Antisemitisme in Nederland rond de bevrijding (Amsterdam: SDU, 1990), 79-85; "Bitter Homecoming: The Return and Reception of Dutch and Stateless Jews in the Netherlands," in The Jews Are Coming Back, 108-35; and Michal Citroen, $U$ wordt door niemand verwacht. Nederlandse joden na kampen en onderduik (Utrecht: Spectrum, 1999), 87. For some examples in Belgium: National Archives Brussels, Alien Police (1930-1960), Individual Aliens' Files (hereafter AAPi), A310595, A386927, A295145, A360179, and Frank Caestecker, "Joodse vluchtelingen in West-Europa voor en na de Holocaust (1933-1950)," Driemaandelijks Tijdschrift van de Auschwitz Stichting 89-99 (2000): 96-97.

70. Bob Moore, Victims and Survivors. The Nazi Persecution of the Jews in the Netherlands 1940-1945 (London: Arnold, 1997), 229-32; Hondius, Terugkeer, 79-84; Berghuis, Geheel ontdaan van onbaatzuchtigheid, 24.; and Bossenbroek, De Meelstreep, 268. 
Jewish Welfare Board in the United States of this situation. The Comite des Réfugiés Victimes des Lois Raciales (COREF), an organization of German Jews residing in Belgium, in turn passed on details to the Jewish Telegraphic Agency. ${ }^{71}$ The Belgian embassy in Washington considered the resultant publicity to be detrimental to Belgian interests. ${ }^{72}$

This narrowly legalistic treatment of German Jews as enemies was not always applied literally throughout Belgium however. The mayor of Antwerp, Camille Huysmans, as early as September 1944, had already sent instructions to his communal police that German Jews were not to be interned merely because they were German, but only if there was strong evidence against them. Ten days after the publication on October 6, 1944 of the formal decision to intern all Germans as enemy aliens, the Belgian minister of justice followed Huysmans' example and urged local authorities throughout the country to exercise their discretion wisely and not to intern Germans who had clearly not collaborated during the occupation. ${ }^{73}$

Dutch policy targeting German Jews went even further. Whereas in Belgium everybody who had a right of abode prior to the war, including Jews deported by the Germans, could return, this was not the case in the Netherlands. Dutch border guards were instructed in May 1945 to deny access to foreigners, including those German Jews returning from concentration camps, even if they had had a right of abode in the Netherlands prior to the war. This insensitive Dutch policy toward Jewish refugees was quickly formally reversed, but the authorities only halfheartedly counteracted it in practice. German Jews still had to be surveilled and, if possible, expelled, not so much because of their alleged collaboration with the enemy, but in order to preserve what was considered to be the "national character" of Dutch society. ${ }^{74}$ Pursuant to this policy, in September 1945, Dutch authorities decided to repatriate all Germans without distinction, but in the planning phase, an exception was very quickly granted to prewar refugees from Germany. All these refugees, including those who

71. National Archives Brussels, Alien Police (1930-1960) (hereafter AAP), 288; and Veerle Vanden Daelen, Laten we hun lied verder zingen: de heropbouw van de joodse gemeenschap in Antwerpen na de Tweede Wereldoorlog (1944-1960) (Amsterdam: Aksant, 2008), 62.

72. AAP, 288.

73. Vanden Daelen, Laten we hun lied verder zingen, 62; and Caestecker, "Holocaust Survivors in Belgium 1944-49," 359.

74. Dienke Hondius, Terugkeer: Antisemitisme in Nederland rond de bevrijding (Amsterdam: SDU, 1990), 79-85; "Bitter Homecoming: The Return and Reception of Dutch and Stateless Jews in the Netherlands," in The Jews Are Coming Back, 108-35; and Michal Citroen, $U$ wordt door niemand verwacht. Nederlandse joden na kampen en onderduik (Utrecht: Spectrum, 1999), 87. 
returned from Germany, would receive a temporary residence permit. ${ }^{75}$ In the summer of 1946, Dutch authorities changed their formal legal position and agreed that the Allied Control Council decision to abrogate Nazi racial legislation had no legal effect beyond German territory. The Dutch government now, for the second and final time, classified German Jews who had been stripped of their German citizenship in 1941 as stateless. ${ }^{76}$

In Belgium, the authorities continued to consider Jews from Germany as Germans and refused to recognize them collectively as victims of Nazism. Jewish Germans who had not collaborated were exempted from official distrust only on a case-by-case basis. They were still subject to strict police control, under which they had to report regularly to the authorities. Only in April 1945, and mainly because of international pressure, was this police surveillance removed from German Jews whose loyalty during the war had been officially confirmed. The entry "non-enemy" now appeared on their Belgian residence permits, next to their newly recognized German nationality. ${ }^{77}$ Another important legal effect of German nationality was that all assets of these Jewish Germans, as enemy aliens, were frozen. ${ }^{78}$ German Jews had to wait for almost 2 years to be treated differently from other Germans in relation to the question of their sequestered assets. A law passed on January 13, 1947 finally recognized that there was a difference between Jewish and other Germans. The law formally permitted German Jews to freely dispose of their property, which, until then, had remained under custodianship. ${ }^{79}$

75. On the deportation of Germans, see Melchior Daniël Bogaarts, "Weg met de moffen" De uitwijzing van Duitse ongewenste vreemdelingen uit Nederland na 1945," in Parlementaire geschiedenis van Nederland na 1945: De periode van het kabinet-Beel (3.7.1946-7.8.1948) (Hague: SDU, 1989), 1716-39; and Jan Sitmaartensdijk and Yfke Nijland, Operatie Black Tulip: De uitzetting van Duitse burgers na de oorlog (Amsterdam: Boom, 2009).

76. Berghuis, Geheel ontdaan van onbaatzuchtigheid, 29-30; and Bossenbroek, De Meelstreep, 262-70.

77. Belgisch Staatsblad, April 25, 1945 and June 6, 1945; Caestecker, "Holocaust Survivors," 358-59; and Notes on the activities of the representative of the Committee in Brussels, July 30, 1945. Archives nationales de la France, AJ 43-58.

78. In Belgium, the property of Jews classified as Germans was confiscated pursuant to the law of August 23, 1944 (Belgisch Staatsblad, September 4, 1944) and the ministerial decree of October 6, 1944.

79. Belgisch Staatsblad, January 23, 1947; Caestecker, "Holocaust Survivors"; and Notes on the activities of the representative of the Committee in Brussels, July 30, 1945. Archives nationales de la France, AJ 43-58. From November 1944, the unblocking of bank accounts had been possible on an individual basis, contingent on a positive vetting report and the recommendation from the Jewish resistance movement, the Comité de Défense des Juifs. Nico Wouters, "De naoorlogse erkenning," in Gewillig België: Overheid en Jodenvervolging 
In France, the decision of the Court of Cassation in November 1946 to collectively restore the original nationality of exiled German Jews met with direct and indirect opposition from other courts, particularly in Paris. Many French judges simply refused to follow the reasoning of the Court of Cassation or to give extended effect to the decision in Kurzmann. In the Téroch c. Daudin case, for example, the 6th Chamber of the Parisian Court set out in detail its reasons for recognizing the statelessness of a former German Jew. The Court found that Control Council Law No. 1 was limited territorially to occupied Germany, and temporally to a prospective effect. ${ }^{80}$ Judicial resistance to the line adopted by the Court of Cassation in Kurzmann spread. The Court of Appeal in Colmar, which had originally followed the more restrictive line of the Kurzmann decision, held in Lennhof c. Brach that because Law No. 1 could have no retroactive effect, a former German Jew remained stateless. ${ }^{81}$

The opposition of other tribunals to the decision of the Court of Cassation in Kurzmann was not only motivated by traditional legal interpretive reasons about the limited temporal and territorial effect of Control Council Laws. French judges also found that the position taken by the Court of Cassation led to basic injustice. They argued that the abolition of Nazi race laws could not have the contradictory effect under a newly re-established French republican legality of worsening the position of those who had been the victims of Nazi anti-Semitism by excluding them from the application of French legal norms meant to alleviate the suffering of the victims of Nazi racist persecution. ${ }^{82}$ In addition, judges argued that the legislature had specified a privileged treatment for stateless Jews when France had ratified the 1938 Geneva Convention for Refugees coming from Germany by the decree of April 14, 1945. This ratification was interpreted by the courts as a clear sign that the republican government sought to undo the iniquities of the Vichy regime and to put into effect a series of policies that would be sympathetic to the victims of Nazi persecution. ${ }^{83}$

Finally in 1950, in Gunguéné c. Dile Falk, the Court of Cassation acknowledged that the abolition of Nazi anti-Jewish laws did not have a retroactive effect. Therefore, the abrogation of Nazi anti-Jewish laws by

tijdens de Tweede Wereldoorlog, ed. Rudi Van Doorslaer, (Antwerp: Meulenhoff-Manteau, 2007), 1064-65.

80. La Semaine Juridique, 1947/21/5504.

81. Gazette du Palais, 1948/II/110-11; Lyon c. Ziegler and Fritsch-Burgart, Revue Critique de droit international privé 39 (1950): 574-77, Court of Appeal Colmar.

82. La Semaine Juridique, 1947/21/5504.

83. Frust Mezger, "Le statut des Refugiés provenant d'Allemagne, selon la Convention de Genève du 10 Février 1938," Nouvelle Revue de Droit International Privé 13 (1946): 56100 . 
the Control Council did not impose German nationality on denationalized German Jews. ${ }^{84}$ This final judgment of the Court of Cassation recognized that its previous interpretation of the abolition of Nazi anti-Jewish laws had caused an injustice to those stateless Jews whom the French legislators had shown an explicit willingness to protect by ratifying the 1938 German Refugee Convention. ${ }^{85}$ Therefore, by 1950 , the French judiciary had reversed its position, and realigned itself with the position that the allied forces in occupied Germany had taken in 1945-1946. German nationality should not be imposed on Jews automatically and without individual consent.

\section{The National Interest of Asylum Countries and the Stateless Jews}

The desire to restore the citizenship of stateless former German Jews was not only attributable to ideological convictions about the re-establishment of liberal values; it was also grounded in the desire to establish and preserve each state's sovereign power. The stateless, as mentioned, had no state affording them protection; however, at the same time, no state had to accept them if they were forcibly expelled from another country. During the interwar period, Western European states had experienced great difficulties in removing undesirable aliens who were stateless because no other country wanted to grant them admission. Also, although only a few jurisdictions granted the stateless (minimal) legal concessions, national courts had imposed some legal limits on a government's arbitrary powers to remove stateless aliens. ${ }^{86}$ Statelessness, as Arendt argued, had been at this time a legal position on which aliens could capitalize to obtain a right of abode or at least to prevent their swift expulsion. For British, Belgian, and Dutch officials, in the postwar period, there was a clear imperative to restore German nationality, with the unambiguous goal of returning these exiled German Jews to their "homes" or to a third country. A British Home Office representative wrote that "... the aim should be to see that the refugees in this country and elsewhere are provided with some

84. Raymond Sarraute and Paul Tager, "La Condition des Étrangers," Revue Critique de Droit International Privé 39 (1950): 580-91; and Alex Weill and Michel Virally, "Du contrôle exercé par la Cour de cassation sur l'interprétation des lois du Conseil de contrôle en Allemagne," Revue Critique de Droit International Privé 41 (1952): 253-75.

85. Ruby, L'Évolution de la Nationalité Allemande, 267.

86. Maximilien Philonenko, "Expulsion des Heimatlos, jurisprudence et pratique administrative," Journal de droit international 64 (1937): 699-707; B. Trachtenberg, "Expulsion des Apatrides," Revue de droit international et de législation comparée 17 (1936): 552-63; and Maximilien Philonenko, "Expulsion des Heimatlos," Journal de droit international 60 (1933): 1161-87. 
nationality and with some country to which they can return if they wish, or to which they can be sent if necessary." 87

The authorities in each nation wanted to avoid any action that might result in large numbers of German Jewish survivors settling in their country. ${ }^{88}$ Very few German Jews wished to return to or went back to Germany. According to the representative in Belgium of the Intergovernmental Committee for the Refugees, almost no German Jews even considered the possibility. Those few who did return voluntarily to Germany were often considered as traitors by their fellow Jews. ${ }^{89}$ The majority of surviving German Jews opted not to return and turned their backs on a country that had turned its back on them. In the end, only approximately $4-5 \%$ of denationalized German Jews chose to return. ${ }^{90}$ The decision whether to return to Germany or not was usually grounded in highly personal circumstances and choices. ${ }^{91}$ For example, the approximately 3500 Jews who returned to East Germany did so almost universally out of socialist political conviction. ${ }^{92}$

Notwithstanding this reluctance of Jews to return to Germany, the Dutch and Belgian and to a lesser extent the British authorities, insisted that the Jewish refugees from Germany had to move elsewhere. ${ }^{93}$ German Jews did

87. Sir F. Newsam to the Control Commission, May 28, 1945, HO 213/951, National Archives, Kew.

88. In the Dutch case, the objective was an explicitly ethnically exclusive immigration policy: Hondius, Terugkeer, 79-85; Berghuis, Geheel ontdaan van onbaatzuchtigheid, 24; and Frank Caestecker, Vluchtelingenbeleid in de naoorlogse periode (Brussels: VUBPress, 1992), 72.

89. Rapport du délégué en Belgique du comité intergouvernmental pour réfugiés, pour la période du 1.7 au 30.9.1946, 7, Archive United High Commissioner of the Refugees, Brussels, Annual Reports.

90. Maitz Krauss, "Westliche Besatzungszonen und Bundesrepublik Deutschland," in Krohn Claus Dieter, Patrick von zur Mühlen, Gerhard Paul und Lutz Winckler (Ed.), Handbuch, Handbuch der deutschsprachigen Emigration 1933-1945 (Darmstadt: Primus, 1998), (n. 146) coll. 1161 ff.; Maritz Krauss, Heimkehr in ein fremdes Land: Geschichte der Remigration nach 1945 (Munich: C. H. Beck Verlag, 2001), 7. Austrian Jews faced a further complication surrounding the legal and political consequences of the Anschluss, and by 1952 , only 4500 Austrian Jews had returned, a mere $4 \%$ of the survivors. Hannelore Burger and Harald Wendelin, "Vertreibung, Rückkehr und Staatsbürgerschaft. Die Praxis der Vollziehung des Staatsbürgerschaftsrechts an den österreichischen Juden," in Staatsbürgerschaft und Vertreibung, ed. Dieter Kolonovits, Hannelore Burger, and Harald Wendelin, (Vienna: Oldenburg, 2004), 374.

91. M. Krauss, "Westliche Besatzungszonen und Bundesrepublik Deutschland."

92. Frank Stern, "The Return to the Disowned Home: German Jews and the Other Germany," New German Critique 67 (1996), 57-72; and "La situation en Allemagne Orientale," in Ruby, L'Évolution de la Nationalité Allemande, 345-52.

93. In Denmark, where the statelessness of Jewish refugees had never been questioned after the war, as early as the spring of 1946 all prewar refugees acquired a right of abode. 
not necessarily have to return home, but they were expected to find another country of refuge. British policy makers still sought to avoid practical, political difficulties and injustices. They continued to insist that the restoration of German nationality was a necessary consequence of the repeal of Nazi anti-Jewish laws. Nonetheless, no Jew would be forcibly repatriated to Germany unless and until the safety of returning Jews could be guaranteed and there was a "reasonable opportunity of earning his livelihood." 94 In Belgium and the Netherlands, pressure to make the Jewish refugees leave was stronger still. Even when, in the summer of 1946, the Dutch authorities had agreed to recognize the statelessness of the former German Jews, they still hoped to be able to repatriate some of them. According to Dutch authorities, a final decision concerning their German nationality was still pending, and granting them a permanent right of abode was not opportune. Until the end of the 1940s, in the Low Countries, a strict individualized path to Dutch citizenship was the only way for these Jews to acquire a permanent right of abode. ${ }^{95}$

\section{“German" Jews No Longer Want to Be Germans}

After the defeat of Nazism, although welcoming the elimination of Nazi anti-Jewish legal provisions, Jewish refugee groups were wary about the effect of this general abrogation on nationality questions. Rabbi Schoyer, the Chairman of the Association of Jewish Refugees in Great Britain, wrote "But the great number of us who do not trust that there will be a quick change of mind of the German people .......wish most earnestly not to be forced back into the status of German nationals by well-meant but rash legislation." 96

Responsive to the wishes of refugee Jews, the Intergovernmental Committee on Refugees had already suggested in April 1944 that the restoration of German nationality should be accompanied either by an "optout" clause permitting refugees to declare within a determined period that they did not wish to accept German nationality, or, alternatively, by an "opt-in" clause by which individuals would be allowed within the

Hans Kirchoff and Lone Rünitz, Udsendt til Tyskland. Dansk flygtningepolitik under besaettelsen, (Odense: Syddansk Universitetsforlag, 2007).

94. Minute Sheet, Home Office Aliens' Department, October 1945, HO 213/951, National Archives, Kew; Foreign Office Memorandum.

95. Berghuis, Geheel ontdaan van onbaatzuchtigheid, 29-30; Bossenbroek, De Meelstreep, 262-70; and Caestecker, Vluchtelingenbeleid, 65-84.

96. Rabbi Schoyer to Emerson, Intergovernmental Committee on Refugees, October 5, 1944, HO 213/199, National Archives, Kew. 
same time frame to positively elect to (re)become German nationals. ${ }^{97} \mathrm{By}$ July 1945, the Intergovernmental Committee had refined its position and insisted that the "opt-in" mechanism was to be preferred "on grounds of equity" and to "avoid any idea of compulsorily imposing an unwanted nationality on exiled Jews". 98

In Belgium in 1944, immediately after the restoration of the German citizenship of Jewish exiles and refugees, many of the formerly German Jews still remained stateless, because their citizenship had been revoked by the Nazis before May 10, 1940, and as a result, they did not fall under the terms of the relevant ministerial Decree. On their Belgian identity cards they were still described as stateless, but of German origin. They demanded that any reference to their original German citizenship be removed from all official documents. They collectively opposed even this bureaucratic indication of their origins. The Belgian authorities ultimately agreed that it could be removed. ${ }^{99}$ This was a harbinger of things to come.

In 1944, immediately after the liberation, the organization of German Jews in Belgium, COREF, also strongly opposed the decision to restore German nationality. Their objections went beyond the obvious adverse effects of such an action; being equated with the Nazi enemy, sequestration of their property, and the danger of being forced to return to Germany. The organization explained their resolve never to be called "German" again to the authorities.

The atrocities of the Nazis have given to the word "German" an uncanny sinister sound. The DPs of German origin have to live with identity cards giving their nationality as "German". To be mixed up in this way with their greatest enemies is a gross injustice. Their hate against everything connected with Germany and the Germans is so deeply rooted that they will never forget nor forgive. Therefore...everything should be done to help these persons to get rid of the ominous and incriminating designation as "German". ${ }^{100}$

97. Memorandum, April 9, 1944, Certain administrative measures by the Occupation Authorities of Germany and Austria relating to nationals or former nationals of those countries who are the victims of Nazi persecution, HO213/951, National Archives, Kew. On the Intergovernmental Committee on Refugees, see Tommie Sjöberg, The Powers and the Persecuted: the Refugee Problem and the Intergovernmental Committee on Refugees (Lund: Lund University Press, 1991).

98. Letter of July 24,1945 to Allied Control Commission, HO 213/951/952, National Archives, Kew. According to Ruby, the Soviet Union adhered to the opt-out principle, L'Évolution de la Nationalité Allemande, 260.

99. Head of the population department of Vorst commune to Aliens' Police Brussels, November 29, 1944. AAP, 20 (1B6/9/4).

100. COREF, Memorandum submitted to Sir Herbert Emerson, November 28, 1945. Archives nationales de la France, AJ 43-58. 
COREF would continue to call upon the authorities to revoke this legal and existential injustice embodied in Belgian legislation. Although by 1947 , most of the adverse effects on exiled German Jews of a restored German nationality had been abrogated, the opposition of Jews to their German citizenship or any mention of their German origins, remained vehement. ${ }^{101}$

Exiled German Jews in these Western European countries expressed the vociferous desire to be recognized as stateless victims of Nazism and rejected any claim that they be treated as reinstated "German" citizens. ${ }^{102}$ The German language distinction between Staatsangehörigkeit, (legal membership in a state in the sense of formal citizenship), and Staatsbürgerschaft, was at the heart of the Jews' objection to being considered "German". Staatsbürgerschaft refers more precisely to the concept of citizenship in the sense of participating in the social life of a particular society. These exiled Jews understood nationality as much more than a simple concept referring to a legal status of individuals in relation to a state. For those German Jews who rejected the restoration of their former nationality, the debates about their status, although formally situated at the level of technical questions within a restrictive legal normativity, were nonetheless informed by an experiential and political understanding of citizenship as belonging (or not) to a society, with a common sense of culture, history and identity, feelings that they longer shared with their former countrymen and women. ${ }^{103}$

This deeper existential meaning of nationality and citizenship was most often ignored by official decision makers who operated within the narrower understandings of nationality derived from domestic and international legal norms. Formally denationalized German Jews rejected the idea that they could become German nationals once again by the simple legal normative abrogation of Nazi race laws. What they had experienced under National Socialism and eventually during their period of interment, imprisonment, exile, and refuge, had removed any sense of belonging to a German nation or sharing anything with a culture that had given Auschwitz to the world. They no longer considered themselves to be "German." They had no desire to return to their previous homes or to seek the legal protections afforded to nationals of the German state. ${ }^{104}$

101. Caestecker, "Holocaust Survivors," 360-80.

102. Given the unique sources available on Belgium, we limit the focus of our analysis of the position of the Jewish refugees themselves to the Belgian case.

103. Margarete Myers Feinstein, Holocaust Survivors in Postwar Germany, 1945-1957, (Cambridge and New York: Cambridge University Press, 2010), 302-8.

104. Anthony Grenville, Jewish Refugees from Germany and Austria in Britain 19331970, (Edgeware and Portland, OR: Vallentine Mitchell, 2010), 52-77. 
A return to liberal legality and rule of law norms, as well as some emerging "human rights" understandings of international law, appeared at first blush to dictate a principled rejection of all Nazi persecutory measures by triumphant democracies. However these victims of Nazi persecution wanted to accept the consequences of the Nazi regime both pragmatically and legally. They rejected their German national origins and saw in their status as "non-nationals" a source of identity, and as Arendt underlined, in some circumstances, however temporarily, political power. Statelessness was for them preferable to "Germanness."

In Belgium, as mentioned, all Jews who had been collectively rendered stateless in 1941 under the 11th Decree, were, with liberation, unequivocally restored to their previous status as German nationals. These Jews who had (re)become reluctant Germans started a long struggle against what they considered to be a fundamental injustice. The restoration of German nationality was considered a clear expression of official insensitivity toward their suffering as Jews under the Nazis. ${ }^{105}$ Numerous German Jews in Belgium asked not to be categorized as Germans. Some went to considerable individual lengths to prove that they had lost their German citizenship. ${ }^{106}$

Sigmund K., a German Jew who had been granted asylum in Belgium in 1936, but who had fled during the war to the United States, appealed against the Belgian decision to consider him German and to sequester his property. He insisted that he had left Germany in 1936, and that as an emigrant, he had forfeited his German citizenship. He asserted that the Belgian government, as a party to the Hague Convention on nationality law, should accept the German decision that rendered him stateless. In July 1946, an Antwerp court acknowledged this argument, and recognized that only the German state could decide who its subjects were. It concluded that he had been denationalized by the German law of November 24, 1941 and declared Sigmund K. to be "stateless." Paul de Streel, a high-ranking civil servant in the Aliens Police, was shocked by this apparently antiliberal rule of law line of reasoning: "How can one accept that a law which only denationalized the German subjects who were Jews and this only to be able to confiscate their property more easily is a law in conformity with international custom and the international legal principles generally accepted in the domain of nationality legislation?" De Streel was sure that the

105. COREF to Vermeylen, October 6, 1948. Maurice Goldstein to Vermeylen, December 26, 1946. Archives Auschwitz Foundation Brussels, Maurice Goldstein Papers, 12.

106. AAPi, A 178748, A 143829. 
judgment of the Antwerp court was une décision de circonstance that would not set a binding precedent. ${ }^{107}$

Hans Handovsky, an Austrian national who had worked at the University of Ghent since 1934, was among those who protested most vehemently against the Belgian decision to restore his German nationality. Handovsky had received his Ph.D. in pharmacology from the University of Vienna, and in 1912 had begun to work at the University of Göttingen. As a Jew, he lost his university post in 1933. The next year, he found a job at the University of Ghent. The application of German anti-Jewish decrees during the war meant that Handovsky had lost his post at this Belgian university as well. The "restoration" of his German nationality not only meant a loss of the residency status he had acquired in the 1930s, but it also led to the incongruous result that he, as an Austrian and Jew, was awarded German citizenship by the Belgian government. This decision effectively re-instituted the Anschluss in his individual case. He insisted on retaining his residence permit based on his status as a stateless foreigner. The mayor of Ghent, Edward Anseele Jr., supported his plea. Exceptionally, the central authorities agreed in April 1945 that he could be registered as stateless and keep his residency permit. All other German Jews in Ghent were refused any such exemption and were officially and legally recognized as having German nationality. ${ }^{108}$

Ernst Klein, a physician from Jena, was among those Jews who were less successful than Handovsky. He had been granted refugee status in Belgium in 1936 because he and his Aryan fiancée had been persecuted in Nazi Germany under the "race defilement" (Rassenschande) provisions of the Nuremberg Laws. ${ }^{109}$ After the war, when he left his hiding place in the commune of Vorst, the local authorities wanted to issue him a temporary residence permit identifying him as a German national. He was resolute in claiming his status as a stateless person. When after 6 months he still refused to yield to the demands of the administration, the Aliens Police threatened to intern him as a danger to public order. They insisted that the local authorities in Vorst enforce their original decision with immediate

107. Ibid., A1.355.126; Staatsarchiv Hamburg, 351-11 Amt für Wiedergutmachung 14249 and 21191, Landgericht Wiedergutmachung 810 (E) 778/58. We thank Beate Meyer and Margot Löhr for sharing the German information with us.

108. Marc Verschooris, In de schaduw van de dood : over thuiskomen, opduiken en achterblijven 1940-1945 (Ghent: Snoeck, 2005), 91; Archive University of Ghent, Files, 6 D1/ 2, 1940/41 Zitting VI 14 March 1941 and 4H 21/1, box 137 "Handovsky, Hans"; and Ghent City Archive, Aliens Files, Handovksy.

109. Frank Caestecker and David Fraser, "The Extraterritorial Application of the Nuremberg Laws: Rassenschande and 'Mixed' Marriages in European Liberal Democracies," Journal of the History of International Law 10 (2008): 35-81. 
effect. On April 23, 1945 Dr. Klein finally gave in and received a temporary residence permit identifying him as a German national. In May 1945, "non-enemy" was added next to the German nationality on the residence permit of Ernst Klein, because, according to the local authorities, his attitude during the war had been "correct." 110

In Belgium, no collective solution was available to the vast majority of those Jews who had no desire to be recognized again as German. As in the Netherlands, the only available mechanism was to apply individually for citizenship. Ernst Klein became a Belgian in 1947.111 In 1948, Hans Handovsky exchanged his "stateless" status for Belgian citizenship. ${ }^{112}$ It was not until 1951 that Belgium conformed to what had become the international standard when it recognized the statelessness of exiled German Jews once again. At that time, the Basic Law of the Federal Republic of Germany recognized the real practical and legal impact of Nazi measures that had deprived German Jews of their nationality. German law under the newly democratic government of the Federal Republic again gave formal effect to the consequences of the 11th Decree, and created an opt-in possibility for all former German Jews who wished to re-assert their original citizenship rights. ${ }^{113}$ Only when Germany regained its sovereignty and the country's nationality law clearly confirmed the statelessness of exiled Jews from Germany, did the ambiguity of their legal status finally disappear. ${ }^{114}$

\section{Conclusion}

Lauterpacht had underlined the ways in which justice for the victims of Nazi persecution could be achieved by a reading of operative international law norms that was consistent with the actual position of former German Jews. He echoed Arendt's contention that stateless was preferable to German nationality for these Jewish refugees from Nazism.

The persons in question were originally deprived of their nationality in the course of a racial and religious persecution unprecedented in history. Their denationalization did not merely sever a formal tie with their country of

110. AAPi, A217.500.

111. Ibid.

112. Ghent City Archive, Aliens Files, Handovksy; Verschooris, In de schaduw van de dood, 92.

113. Oppenheimer v. Cattermole (1976) A.C. 249.

114. Weis, Nationality and Statelessness in International Law, 121. Belgisch Staatsblad, 30.3.1951 and 9.2.1952. 
origin. They were cut off, amidst calculated and prolonged indignities and humiliation, from any sort of community with the people of that country. Their livelihood and their property were destroyed and confiscated. Their relatives and co-religionists were subjected to a spiritual and physical persecution which shocked and outraged civilized mankind. The deprivation of nationality was a link in the chain of that ruthless persecution. However, in some ways, that particular measure proved for those resident abroad a source of protection. During the war statelessness became for many of them a status preferable to that of the nationality of a belligerent state. ${ }^{115}$

Belgium, the Netherlands, Britain, and France eventually arrived at a legal and/or political solution that reflected, to a greater or lesser extent, the demands of justice in such cases. Each national case was influenced by geopolitical considerations and the complexities of domestic politics, as well as by technical demands and interpretations of international law. In the Netherlands and Belgium, the situation was fraught with internal frictions between and among various parts of the Jewish community and the desire of the bureaucracy to see these foreign Jews move on. In France, domestic concerns over Vichy's own denaturalization of thousands of Jewish citizens, and a narrowly state-centric restoration of the republican norms of legality by the Court of Cassation, created their own difficulties. In Britain, the Palestine question loomed large, as did the fear of large numbers of Jews electing to stay in the United Kingdom at the war's end.

Although the restoration of German nationality for exiled Jews appeared at first blush to be the best, most natural, and most consistent way of manifesting the complete rejection of the notion of "Nazi law," the practical consequences of such a step led to the postwar internment of German Jews alongside Nazi perpetrators and the freezing of their assets, in addition to the deprivation of rights to compensation for victims of Nazi racial persecution. Only by giving effect to the 11 th Decree and recognizing the statelessness of former German Jews, could the liberal democracies of Western Europe begin in some small way to undo the injustices of the Nazi legal regime of anti-Semitic persecution. For Arendt, the answer was not to be found in the narrow traditional international legalism entwined in the nation state paradigm, but in a nascent human rights normativity. "The question, rather, is one of rescuing the stateless from the tyranny of arbitrary legislation and the chaos of police rule and of somehow restoring them to the inalienable rights of man." 116

A narrow state-centered approach to international law had to give way to the demands of equity and justice. Arguments were mustered that invoked

115. Lauterpacht, "The Nationality of Denationalized Persons," 174.

116. "The Stateless People," 153. 
other international law norms - such as the territorial limitations of Control Council jurisdiction, the abhorrence of retrospectivity - in order to give a gloss of legal respectability to the ethical demands and political reality, which ironically called for giving ongoing effect to the Nazi 11th Decree.

This recognition of the juridical impact of the denationalization decrees by liberal legal systems also came close to the complex reality being experienced by many former German Jews themselves. The deprivation of German nationality was something that many experienced not just as a technical legal measure imposed by a National Socialist regime, but also as an existential break with their former lives. They experienced in concrete ways the distinction between nationality understood as membership in a state as a matter of national and international law, (Staatsangehörigkeit), and the broader sociological and political notions of citizenship as belonging to an identifiable national society, (Staatsbürgerschaft). They did not wish to return to a Germany in which reality conflicted brutally with an imagined and no longer existing citizens' Heimat. Ironically perhaps, statelessness was, in the Arendtian sense, truly a status that conferred on them an accurate political understanding of their current place, however temporary, in the world. The demands of equity and justice also implied that being stateless was not to be equated with the deprivation of individual's rights. The political power that they as stateless could muster caused a provisional breach in the traditional state-centered international order. These German Jews, and perhaps other DPs as well, provoked transient concessions from nation-states to human rights, a change that went beyond mere geopolitical and other pragmatic considerations. 